\title{
Thermal Analysis and Electron Probe Microanalysis of the AK6 Aluminum Alloy
}

\author{
P. L. Reznik*, V. M. Zamyatin**, and V. S. Mushnikov \\ Ural Federal University, ul. Mira 19, Yekaterinburg, 620002 Russia \\ *e-mail: urfu-science@yandex.com \\ **e-mail: Zamyatin.av@gmail.com
}

\begin{abstract}
Processes of melting the samples of industrial AK6 aluminum alloy in cast and homogenized states are studied using thermal analysis with the subsequent numerical differentiation with respect to time of heating curves in a temperature range from 300 to $670^{\circ} \mathrm{C}$. The temperatures of nonequilibrium solidus, equilibrium solidus, and liquidus are evaluated. The microstructure of cast and homogenized alloy samples is studied and the local chemical composition of the aluminum host and phases is determined.
\end{abstract}

Keywords: AK6 aluminum alloy, thermal analysis, electron probe microanalysis, solidus, liquidus, phase

DOI: $10.3103 / \mathrm{S} 1067821213010173$

\section{INTRODUCTION}

Half-finished products made of the AK6 aluminum alloy are widely used in different branches of industry, particularly in building aircraft [1]. It is known [2,3] that the structure and properties of the ingots obtained using semicontinuous casting followed by homogenization exert hereditary action on the structure and properties of half-finished products.

The purity of the AK6 alloy in regards to the concentration of iron, hydrogen, and nonmetal inclusions has been substantially improved over the last 30 years due to the application of aluminum and foundry alloys of higher grades, as well as out-of-furnace methods of melt refining. As a consequence, the processes of alloy crystallization and the formation of the ingot structure changed. The features of the ingot structure in cast and homogenized states are poorly known, which retards the improvement of technology for the production of halffinished products from the AK6 alloy despite the steady increase in requirements for their mechanical, corrosion, and structural properties.

In this study we fulfilled a thermal analysis and an electron probe microanalysis of the samples taken from ingots of the industrial AK6 aluminum alloy.

\section{EXPERIMENTAL}

The test samples were cut from the central and semiradius $(0.5 r)$ zones of industrial cylindrical ingots of the AK6 aluminum alloy $377 \mathrm{~mm}$ in diameter in the states cast and homogenized according to the serial mode $\left(480-500^{\circ} \mathrm{C}, 4 \mathrm{~h}\right)$. Their chemical composition in different ingot zones is given in Table 1.

The temperatures of phase transformations in cast and homogenized samples were determined using thermal analysis followed by the numerical differentiation of heating curves with respect to time. The experimental features were as follows. Cylindrical samples $16 \mathrm{~mm}$ in height and $16 \mathrm{~mm}$ in diameter with an axial aperture intended for housing the hot junction of a chromelalumel thermocouple was placed into a corundum crucible positioned in a special measuring cell of a thermal analyzer $[4,5]$. The numerical values of thermovoltage were fixed during the monotonic heating of the sample from 300 to $670^{\circ} \mathrm{C}$ with the help of a Sh31 digital voltmeter after identical time intervals $\Delta \tau=5 \mathrm{~s}$.

Due to the fact that the plot of dependence $t(\tau)$ is characterized by smooth transitions, it is very difficult to evaluate the temperatures of solidus, liquidus, and phase transformations with minimal accuracy. To increase the accuracy, dependences $t(\tau)$ were numerically differentiated and the plots were constructed based on the points in coordinates "sample heating rate-sample temperature." Phase-transition temperatures $t$ were determined from these plots with an error of $\pm 0.1^{\circ} \mathrm{C}$.

The electron probe microanalysis (EPMA) of phase components in the samples cut out from cast and homogenized ingots was performed with the help

Table 1. Chemical composition (wt \%) of the samples cut from AK6 alloy ingots $377 \mathrm{~mm}$ in diameter

\begin{tabular}{c|c|c|c|c|c|c|c|c|c}
\hline $\begin{array}{c}\text { Cutting zone } \\
\text { of sample }\end{array}$ & $\mathrm{Cu}$ & $\mathrm{Mg}$ & $\mathrm{Si}$ & $\mathrm{Mn}$ & $\mathrm{Ti}$ & $\mathrm{Zn}$ & $\mathrm{Fe}$ & $\mathrm{Ni}$ & $\mathrm{Al}$ \\
\hline Center & 2.3 & 0.6 & 1 & 0.6 & $<0.1$ & $<0.1$ & 0.1 & $<0.1$ & Rest \\
$0.5 r$ & 2.2 & 0.6 & 1 & 0.6 & $<0.1$ & $<0.1$ & 0.2 & $<0.1$ & $\mathrm{Rest}$ \\
\hline
\end{tabular}



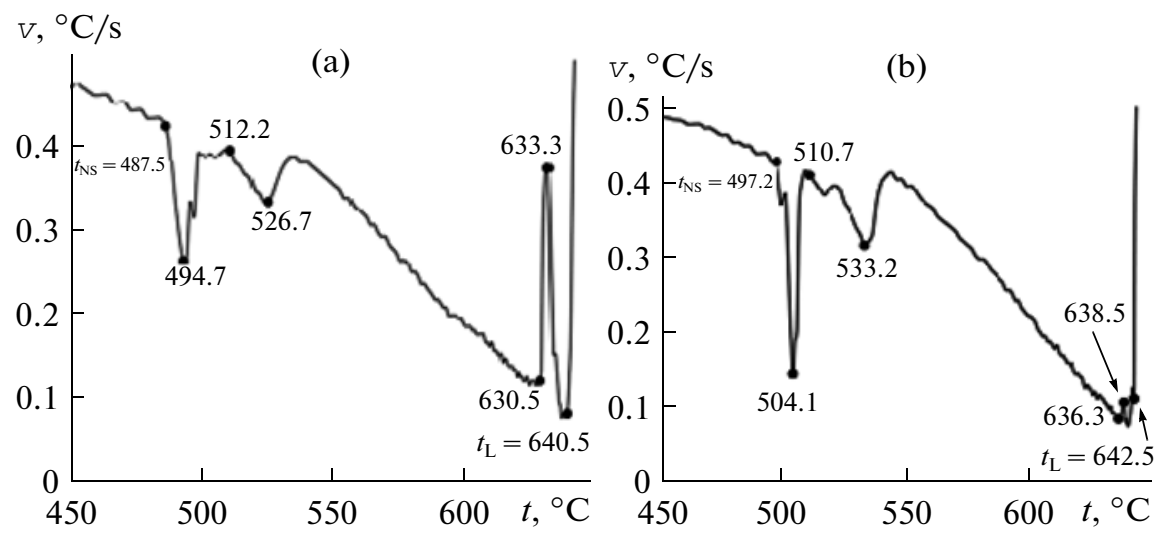

Fig. 1. Thermograms of heating the samples taken from (a) the center and (b) the semiradius zone of the AK6 cast cylindrical ingot $377 \mathrm{~mm}$ in diameter.
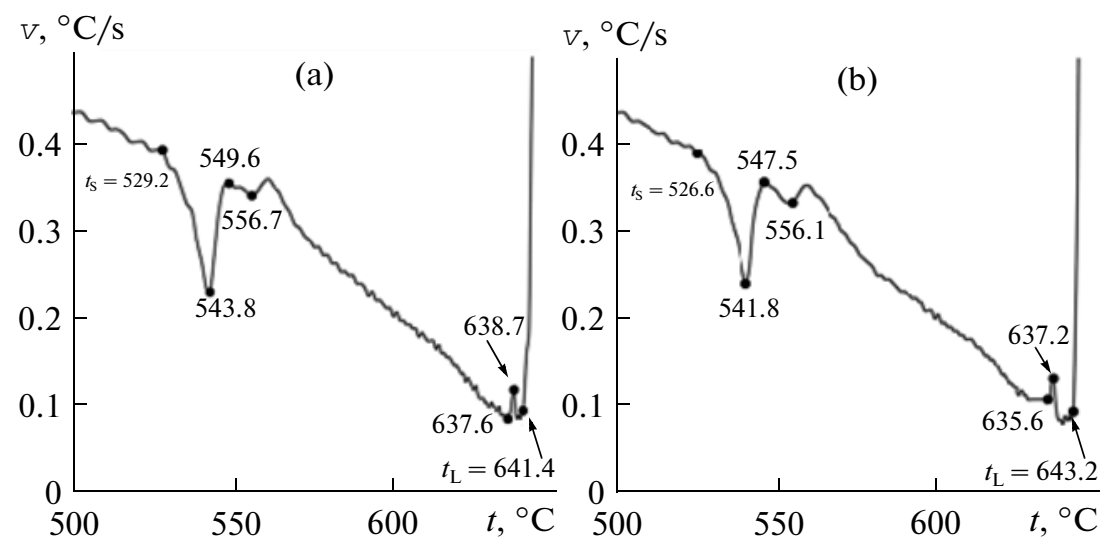

Fig. 2. Thermograms of heating the samples taken from (a) the center and (b) the semi-radius zone of the AK6 homogenized cylindrical ingot $377 \mathrm{~mm}$ in diameter.

of a JSM-5900 LV scanning electron microscope equipped with an electron probe microanalyzer. Relative measurement errors in determining the concentration $(C)$ of chemical elements in the alloy by EPMA were $5 \%$ at $C<10 \%$ and $1 \%$ at $C>10 \%$.

\section{RESULTS AND DISCUSSION}

Figure 1 presents heating thermograms (differential curves) of the samples from the center and semiradius zone of the AK6 alloy cast ingot, which show the temperatures of nonequilibrium solidus $\left(t_{\mathrm{NS}}\right)$ and liquidus $\left(t_{\mathrm{L}}\right)$, as well as of phase transformations in the solid-liquid state. It is noteworthy that the $t_{\mathrm{NS}}$ of the sample taken from the ingot center is lower than that of the sample from the ingot semiradius zone by almost $10^{\circ} \mathrm{C}$. In spite of the similar character of thermograms of the sample from both zones, the temperature ranges of phase transformations in them differ as well (Table 2).

Figure 2 presents heating thermograms of the samples taken from the center and the semiradius zone of a homogenized ingot of the AK6 alloy. They show the temperatures of the equilibrium solidus $\left(t_{\mathrm{S}}\right)$ and liquidus $\left(t_{\mathrm{L}}\right)$, as well as phase transformations in a solidliquid state, the temperature ranges of which are also

Table 2. Temperature ranges of phase transformations in the AK6 alloy upon melting

\begin{tabular}{l|l|c|c|c|c}
\hline \multirow{2}{*}{ Sampling zone } & \multirow{2}{*}{ Ingot state } & \multicolumn{4}{|c}{ Temperature ranges, ${ }^{\circ} \mathrm{C}$} \\
\cline { 3 - 6 } & & $\Delta t_{\mathrm{S}},{ }^{\circ} \mathrm{C}$ & $\Delta t_{1},{ }^{\circ} \mathrm{C}$ & $\Delta t_{2},{ }^{\circ} \mathrm{C}$ & $t_{\mathrm{L}},{ }^{\circ} \mathrm{C}$ \\
\hline Center & Cast & $487.5-494.7$ & $512.2-526.7$ & $630.5-633.3$ & 640.5 \\
$0.5 r$ & Cast & $497.2-504.1$ & $510.7-533.2$ & $636.3-638.5$ & 642.5 \\
Center & Homogenized & $529.2-543.8$ & $549.6-556.7$ & $637.6-638.7$ & 641.4 \\
$0.5 r$ & Homogenized & $526.6-541.8$ & $547.5-556.1$ & $635.6-637.2$ & 643.2 \\
\hline
\end{tabular}


Table 3. Local chemical composition (wt \%) of the phases in a typical region in the section of cast and homogenized samples of the AK6 alloy

\begin{tabular}{|c|c|c|c|c|c|c|c|c|c|c|}
\hline $\begin{array}{l}\text { Point no. } \\
\text { in Fig. } 3\end{array}$ & $\mathrm{Mg}$ & $\mathrm{Al}$ & $\mathrm{Si}$ & $\mathrm{Ti}$ & Mn & $\mathrm{Fe}$ & $\mathrm{Ni}$ & $\mathrm{Cu}$ & $\mathrm{Zn}$ & Total \\
\hline \multicolumn{11}{|c|}{ AK6 cast alloy } \\
\hline 1 & 0.2 & 50.9 & 1.2 & 0 & 0 & 0 & 0.2 & 47.5 & 0 & 100 \\
\hline 2 & 0.2 & 51.4 & 1.3 & 0 & 0 & 0 & 0.2 & 46.9 & 0 & 100 \\
\hline 3 & 0.3 & 51.6 & 1.6 & 0 & 0.1 & 0.2 & 0.1 & 46.1 & 0 & 100 \\
\hline 4 & 0.3 & 59.9 & 10.3 & 0 & 13.5 & 12.0 & 0.1 & 3.9 & 0 & 100 \\
\hline 5 & 0.2 & 66.8 & 9.3 & 0 & 10.6 & 9.2 & 0.1 & 3.8 & 0 & 100 \\
\hline 6 & 0.1 & 60.1 & 9.9 & 0 & 14.3 & 12.3 & 0 & 3.3 & 0 & 100 \\
\hline 7 & 29.5 & 22.7 & 31.3 & 0.1 & 0 & 0 & 0.1 & 16.3 & 0 & 100 \\
\hline 8 & 22.6 & 35.0 & 26.4 & 0 & 0 & 0.1 & 0 & 15.9 & 0 & 100 \\
\hline 9 & 0.3 & 98.4 & 0.1 & 0.1 & 0.5 & 0 & 0 & 0.6 & 0 & 100 \\
\hline 10 & 0.3 & 98.0 & 0.4 & 0.1 & 0.4 & 0.1 & 0 & 0.7 & 0 & 100 \\
\hline 11 & 0.3 & 98.5 & 0.3 & 0 & 0.4 & 0 & 0 & 0.5 & 0 & 100 \\
\hline 12 & 0.5 & 96.9 & 0.6 & 0 & 0.6 & 0 & 0 & 1.4 & 0 & 100 \\
\hline 13 & 0.3 & 95.1 & 1.3 & 0 & 0.1 & 0 & 0 & 3.2 & 0 & 100 \\
\hline 14 & 0.6 & 96.4 & 0.9 & 0 & 0.1 & 0.1 & 0.1 & 1.8 & 0 & 100 \\
\hline 15 & 4.0 & 52.1 & 12.6 & 0 & 0.2 & 0.2 & 0.2 & 30.7 & 0 & 100 \\
\hline 16 & 0.6 & 56.6 & 11.6 & 0 & 0.2 & 0 & 0.2 & 30.6 & 0.2 & 100 \\
\hline \multicolumn{11}{|c|}{ AK6 homogenized alloy } \\
\hline 1 & 28.3 & 25.8 & 30.1 & 0 & 0 & 0.1 & 0 & 15.7 & 0 & 100 \\
\hline 2 & 22.2 & 38.8 & 26.1 & 0 & 0.1 & 0 & 0 & 12.7 & 0.1 & 100 \\
\hline 3 & 24.8 & 31.8 & 28.4 & 0 & 0 & 0.1 & 0 & 14.9 & 0 & 100 \\
\hline 4 & 24.0 & 36.2 & 25.9 & 0 & 0.1 & 0 & 0.1 & 13.7 & 0 & 100 \\
\hline 5 & 0.1 & 62.2 & 10.2 & 0 & 12.4 & 11.1 & 0 & 4.0 & 0 & 100 \\
\hline 6 & 0.6 & 62.3 & 10.3 & 0 & 12.1 & 10.3 & 0.2 & 4.1 & 0.1 & 100 \\
\hline 7 & 0.4 & 59.5 & 10.8 & 0 & 13.3 & 11.4 & 0 & 4.6 & 0 & 100 \\
\hline 8 & 0.1 & 62.5 & 9.6 & 0 & 12.9 & 11.0 & 0 & 3.9 & 0 & 100 \\
\hline 9 & 0.5 & 95.2 & 1.3 & 0 & 0.4 & 0.1 & 0 & 2.5 & 0 & 100 \\
\hline 10 & 0.3 & 95.9 & 0.8 & 0.1 & 0.6 & 0.1 & 0 & 2.2 & 0 & 100 \\
\hline 11 & 0.3 & 96.3 & 0.8 & 0 & 0.5 & 0.1 & 0 & 2.0 & 0 & 100 \\
\hline 12 & 0.2 & 96.5 & 0.7 & 0.1 & 0.4 & 0 & 0 & 2.1 & 0 & 100 \\
\hline
\end{tabular}

listed in Table 2. It is seen from these data that the difference in the solidus temperatures of homogenized samples from different zones of the AK6 cast alloy sample does not exceed $3{ }^{\circ} \mathrm{C}$.

Based on the results of a thermal analysis of the samples taken from the central and semiradius zones
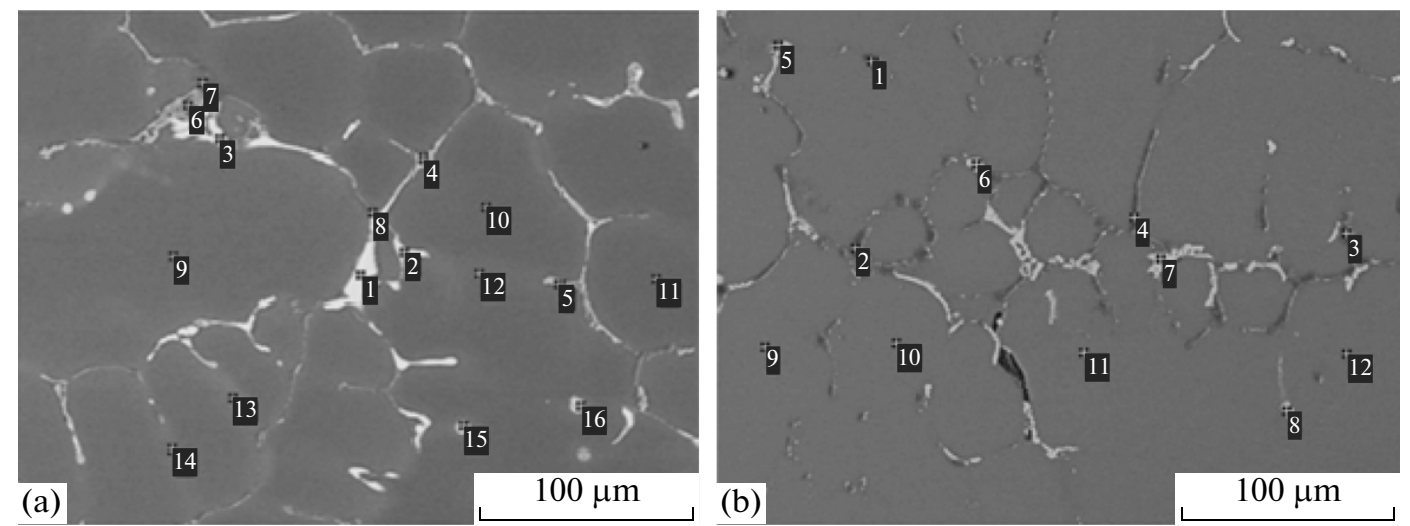

Fig. 3. Typical microstructure of the samples taken from the central zone of (a) cast and (b) homogenized AK6 ingots 377 mm in diameter. of the AK6 cast alloy ingot, the temperature of nonequilibrium solidus is 487.5 and $497.2^{\circ} \mathrm{C}$, respectively. In this case, the melting of a nonequilibrium eutectic is accomplished in a broad temperature range. The homogenization of the ingots in accordance with a serial mode $\left(480-500^{\circ} \mathrm{C}, 4 \mathrm{~h}\right)$ causes the dissolution of 
Table 4. Formulas of phases and spread ranges of contents of alloying elements in hosts of the cast and homogenized samples of the AK6 alloy

\begin{tabular}{|c|c|c|c|c|}
\hline \multirow[b]{2}{*}{ Phase } & \multicolumn{2}{|c|}{ Cast state } & \multicolumn{2}{|c|}{ Homogenized state } \\
\hline & $\begin{array}{l}\text { point no. in Fig. 3a } \\
\text { and Table } 3\end{array}$ & formula & $\begin{array}{l}\text { point no. in Fig. 3b } \\
\text { and Table } 3\end{array}$ & formula \\
\hline 1 & $1,2,3$ & $\mathrm{Al}_{5} \mathrm{Cu}_{2}$ & & - \\
\hline 2 & 15,16 & $\mathrm{Al}_{4} \mathrm{Cu}_{2} \mathrm{Si}$ & & - \\
\hline 3 & 7,8 & $\mathrm{Al}_{4} \mathrm{Mg}_{4} \mathrm{Si}_{4} \mathrm{Cu}$ & $1,2,3,4$ & $\mathrm{Al}_{6} \mathrm{Mg}_{5} \mathrm{Si}_{5} \mathrm{Cu}$ \\
\hline 4 & $4,5,6$ & $\mathrm{Al}_{11} \mathrm{Si}_{2} \mathrm{MnFe}$ & $5,6,7,8$ & $\mathrm{Al}_{36} \mathrm{Si}_{6} \mathrm{Mn}_{4} \mathrm{Fe}_{3} \mathrm{Cu}$ \\
\hline Host (wt \%) & \multicolumn{2}{|c|}{$\begin{array}{c}\text { Points } 9-14: \\
0.3-0.5 \mathrm{Mg}, 0.1-1.3 \mathrm{Si} \\
0.1-0.6 \mathrm{Mn}, 0.5-3.2 \mathrm{Cu} \\
\text { up to } 0.1 \mathrm{Ti}, \text { up to } 0.1 \mathrm{Ni}\end{array}$} & \multicolumn{2}{|c|}{$\begin{array}{c}\text { Points } 9-12: \\
0.2-0.5 \mathrm{Mg}, 0.7-1.3 \mathrm{Si} \\
0.4-0.6 \mathrm{Mn}, 2.0-2.5 \mathrm{Cu} \text {, up to } 0.1 \mathrm{Ti}\end{array}$} \\
\hline
\end{tabular}

the nonequilibrium eutectic in the grains of the aluminum alloy host. In this case, the temperature of the onset of melting of the formed eutectic increases to $529.2^{\circ} \mathrm{C}$ for the sample taken from the center and $526.6^{\circ} \mathrm{C}$ for that taken from the semiradius ingot zone.

The local chemical composition of the phases in the cast and homogenized ingots was determined using the EPMA of polished sections of the source samples. Figure 3 shows electron-microscopic images of typical regions of the slice from the center of the cast and homogenized AK6 alloy samples in backscattered electrons (BSE). Digits denote the points (phases) where the local chemical composition was determined.

It follows from Fig. 3 that the particles of the phases are arranged along the boundaries of dendritic cells and their chemical compositions are rather complex (Table 3). Switching from weight to atomic percentage allowed us to calculate the formulas of individual phases (Table 4). Table 4 also represents the ranges of the spread in contents of alloying elements in the hosts of the cast and homogenized samples.

An analysis of our data shows that nonequilibrium phases $\mathrm{Al}_{5} \mathrm{Cu}_{2}$ and $\mathrm{Al}_{4} \mathrm{Cu}_{2} \mathrm{Si}$ revealed in the cast sample are absent in the homogenized alloy. The composition of the phases formed by major alloying elements (magnesium, silicon, and copper) varies during the homogenization of the ingot. The $\mathrm{Si}$ and $\mathrm{Cu}$ contents in the alloy host substantially increase. The complete dissolution of the formed phases does not occur during the serial homogenization mode of the ingots.

\section{CONCLUSIONS}

The temperature of the onset of melting of the nonequilibrium eutectic (nonequilibrium solidus) in the samples taken from a cast ingot of the AK6 alloy was determined by thermal analysis. It was revealed that this temperature depends on the cutting zone of the samples from the ingot. Chemical compositions of nonequilibrium phases involved in the nonequilibrium eutectic and the alloy host were evaluated with the use of electron probe analysis. It is shown that homogenizing the AK 6 alloy ingots following the serial mode causes an increase in the eutectic temperature by $30-$ $40^{\circ} \mathrm{C}$ depending on the cutting zone of the sample from the ingot. The composition of phases formed by alloying elements and the alloy host substantially varies in this case.

\section{REFERENCES}

1. Struktura i svoistva polufabrikatov iz alyuminievykh splavov: Spravochnik (The Structure and Properties of Half-Finished Products from Aluminum Alloys: Reference Book), Archakov, Z.N., Balakhontsev, G.A., and Basov, I.G., Eds., Moscow: Metallurgiya, 1984, 2nd ed.

2. Dobatkin, V.I., Nepreryvnoe lit'e $i$ liteinye svoistva splavov (Continuous Casting and Casting Properties of Alloys), Moscow: Oborongiz, 1948.

3. Zolotorevskii, V.S., Struktura i prochnost' litykh alyuminievykh splavov (The Structure and Strength of Cast Aluminum Alloys), Moscow: Metallurgiya, 1981.

4. Egunov, V.P., Vvedenie v termicheskii analiz (Introduction to Thermal Analysis), Samara: SamVen, 1996.

5. Smirnov, V.L., Zamyatin, V.M., Ovsyannikov, B.V., and Mushnikov, V.S., Tsvetn. Met., 2009, no. 2, p. 80. 